\title{
Seasonal variation in marine $C: N: P$ stoichiometry: can the composition of seston explain stable Redfield ratios?
}

\author{
H. Frigstad ${ }^{1,2}$, T. Andersen ${ }^{3}$, D. O. Hessen ${ }^{3}$, L.-J. Naustvoll ${ }^{4}$, T. M. Johnsen ${ }^{5}$, and R. G. J. Bellerby ${ }^{6,2,1}$ \\ ${ }^{1}$ Geophysical Institute, University of Bergen, Allégaten 70, 5007 Bergen, Norway \\ ${ }^{2}$ Bjerknes Centre for Climate Research, Allégaten 55, 5007 Bergen, Norway \\ ${ }^{3}$ Department of Biology, University of Oslo, P.O. Box 1066 Blindern, 0316 Oslo, Norway \\ ${ }^{4}$ Institute of Marine Research (IMR), Flødevigen Research Station, Nye Flødevigveien 20, 4814 His, Norway \\ ${ }^{5}$ Norwegian Institute for Water Research (NIVA), Thormøhlensgate 53D, 5006 Bergen, Norway \\ ${ }^{6}$ Uni Bjerknes Centre, Uni Research, Allégaten 55, 5007 Bergen, Norway
}

Received: 7 June 2011 - Published in Biogeosciences Discuss.: 30 June 2011

Revised: 27 September 2011 - Accepted: 3 October 2011 - Published: 18 October 2011

\begin{abstract}
Seston is suspended particulate organic matter, comprising a mixture of autotrophic, heterotrophic and detrital material. Despite variable proportions of these components, marine seston often exhibits relatively small deviations from the Redfield ratio (C:N:P = 106:16:1). Two timeseries from the Norwegian shelf in Skagerrak are used to identify drivers of the seasonal variation in seston elemental ratios. An ordination identified water mass characteristics and bloom dynamics as the most important drivers for determining $\mathrm{C}: \mathrm{N}$, while changes in nutrient concentrations and biomass were most important for the C:P and N:P relationships. There is no standardized method for determining the functional composition of seston and the fractions of POC, PON and PP associated with phytoplankton, therefore any such information has to be obtained by indirect means. In this study, a generalized linear model was used to differentiate between the live autotrophic and non-autotrophic sestonic fractions, and for both stations the non-autotrophic fractions dominated with respective annual means of 76 and $55 \%$. This regression model approach builds on assumptions (e.g. constant POC:Chl- $a$ ratio) and the robustness of the estimates were explored with a bootstrap analysis. In addition the autotrophic percentage calculated from the statistical model was compared with estimated phytoplankton carbon, and the two independent estimates of autotrophic percentage were comparable with similar seasonal cycles. The estimated C:nutrient ratios of live autotrophs were, in general, lower than Redfield, while the non-autotrophic C:nutrient ratios were higher than the live autotrophic ratios and above, or close to, the Redfield ratio. This is due to preferential
\end{abstract}

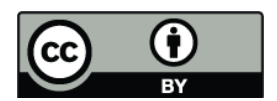

Correspondence to: H. Frigstad (helene.frigstad@gfi.uib.no) remineralization of nutrients, and the $\mathrm{P}$ content mainly governed the difference between the sestonic fractions. Despite the seasonal variability in seston composition and the generally low contribution of autotrophic biomass, the variation observed in the total seston ratios was low compared to the variation found in dissolved and particulate pools. Sestonic $\mathrm{C}: \mathrm{N}: \mathrm{P}$ ratios close to the Redfield ratios should not be used as an indicator of phytoplankton physiological state, but could instead reflect varying contributions of sestonic fractions that sum up to an elemental ratio close to Redfield.

\section{Introduction}

One of the seminal discoveries in marine sciences was that of Redfield (1958) who showed that the relative proportions of carbon $(\mathrm{C})$, nitrogen $(\mathrm{N})$ and phosphorus $(\mathrm{P})$ in suspended particulate organic matter (seston) in the offshore ocean were nearly constant. This observation is usually referred to as the "Redfield ratio"; C:N:P = 106:16:1 (atomic ratios). Seston plays two major roles in the flux of energy and elements in marine systems. Firstly, it constitutes a route from $\mathrm{CO}_{2}$ to organic components and subsequent export of $\mathrm{C}$ to deeper layers (i.e. the "biological pump"), and secondly it forms the base of the marine food web. Many studies have examined the composition of marine seston (Copin-Montegut and Copin-Montegut, 1983; Li et al., 2000; Schneider et al., 2003; Sterner et al., 2008), and the general applicability of the Redfield ratio has been widely discussed since its introduction. For example, recent analyses indicate that seston is more $\mathrm{C}$-rich than the original Redfield ratio (C:N:P=166:20:1; Sterner et al., 2008).

Published by Copernicus Publications on behalf of the European Geosciences Union. 
The Redfield ratio has been considered the "optimum composition for phytoplankton biochemistry, independent of the composition of growth medium" (Lenton and Watson, 2000). However, laboratory culture experiments have shown that nutrient limitation can change elemental ratios by $2-10$ fold, which questions the notion that the Redfield ratio has any physiological or biochemical basis, or that the proportions of elements that primary producers require is fixed (Geider and La Roche, 2002). On the other hand, stoichiometric responses to extreme experimental conditions may not be relevant to mixed communities in natural systems where also other sestonic fractions are included in the response (i.e. different species of autotrophs and heterotrophs in various life stages and detrital particles of mixed origin). Hence to understand the complex dynamics of variable stoichiometry in seston extensive observational dataset are needed. In addition a more fundamental development of the Redfield ratio is required to incorporate the variability of seston elemental ratios with time, region, scale and environmental variables (Michaels et al., 2001; Klausmeier et al., 2008; Sterner et al., 2008).

The understanding of drivers of seston elemental ratios is improving, for example on season and nutrient availability (Körtzinger et al., 2001; Koeve, 2004; Bates et al., 2005), depth (Schneider et al., 2003; Omta et al., 2006), $\mathrm{CO}_{2}$ (Riebesell et al., 2007; Bellerby et al., 2008), light intensity and spectral composition (Hessen, 2008) and productivity or seston mass (Sterner et al., 2008). Recently it has been shown that "circulation averaging", i.e. mixing water masses with contrasting $\mathrm{N}: \mathrm{P}$ ratios, can help to explain the uniform Redfield ratios often observed in the open ocean (Weber and Deutsch, 2010).

It has been shown that including variable stoichiometry in ocean biogeochemistry models better represent important processes, especially those related to vertical and seasonal $\mathrm{C}$ cycling, than using a fixed C:N:P proportionality (Klausmeier et al., 2004; Christian, 2005). Flynn et al. (2010) emphasize that the importance of nutrient limitation on changes in phytoplankton stoichiometry cannot be described by traditional models with fixed proportionality, and that this constraint has implications for modelling not only the nonlimiting nutrients, but also for understanding predator-prey interactions and nutrient recycling. The call to introduce and improve parameterizations of variable stoichiometry in models has emphasized the need to enhance our understanding of the processes driving the natural variability in seston elemental ratios.

In this study we used data from two time-series stations at Arendal and Jomfruland off the Norwegian coast of Skagerrak to address these challenges. These stations offer a unique long-term data-set, documenting vertical profiles of physical, chemical and biological variables, in addition to measurements of Particulate Organic Carbon (POC), Particulate Organic Nitrogen (PON) and Particulate Phosphorus (PP). Using an ordination of defined drivers and a statistical model to assess the share of phytoplankton to total seston mass, we identified processes responsible for the observed seasonal variability in seston elemental ratios. This study is of importance not only for resolving the biogeochemical fluxes of key elements in marine systems, but also for understanding the natural variability in seston and improving the empirical basis for modeling variable stoichiometry. In addition this study provides new understanding of the food quality of sestonic food sources for pelagic consumers (cf. Sterner and Elser, 2002).

\section{Material and methods}

\subsection{Time-series stations}

The Skagerrak is situated in the North-East Atlantic Ocean, between Denmark, Sweden and Norway. It connects the North and Baltic Seas, and has one of the most densely populated catchment areas in the world. It is influenced by freshwater discharges from local rivers and outflow from the Baltic Sea. The circulation of the surface water is on average cyclonic, and consists of the Jutland Current along the west coast of Denmark, which mixes with the Baltic Current, river run-off and more saline Atlantic Water from the west to create the Norwegian Coastal Current (Svansson, 1975).

In 1990 the Norwegian Climate and Pollution Agency established the long-term data series at stations Jomfruland $\left(58^{\circ} 51^{\prime} \mathrm{N} 09^{\circ} 40^{\prime} \mathrm{E}\right)$ and Arendal St. $2\left(58^{\circ} 23^{\prime} \mathrm{N} 08^{\circ} 49^{\prime} \mathrm{E}\right)$ as part of the Norwegian Coastal Monitoring Programme (stations shown in Fig. 1). The Jomfruland station is located 2 nautical miles off the coast with a depth of $125 \mathrm{~m}$, while Arendal St. 2 is located 1 nautical mile off the coast and is $75 \mathrm{~m}$ deep. Both stations are sampled approximately 20 times per year.

\subsection{Data}

The variables from the Norwegian Coastal Monitoring Programme included in the present study were: temperature, salinity, chlorophyll- $a$ (Chl- $a$ ), Dissolved Inorganic Nitrogen (DIN), Dissolved Inorganic Phosphorus (DIP), dissolved silicate $\left(\mathrm{SiO}_{2}\right)$, Total Nitrogen (TotN) and Total Phosphorus (TotP), POC, PON and PP. The water samples for POC, PON and PP were pre-screened with a cloth of pore size $180 \mu \mathrm{m}$ before filtration. To ensure the consistency of measurements and comparability between stations IMR and NIVA participate twice a year in the quality assurance programme QUASIMEME (http://www.quasimeme.org/), in addition to regular inter-calibrations between the two institutions. However, there is a systematic difference in POC and PON between Jomfruland (analysis by NIVA) and Arendal (analysis by IMR) in the Norwegian Coastal Monitoring Programme. The measurements reported by NIVA (including data presented in this work) are thus corrected according to 


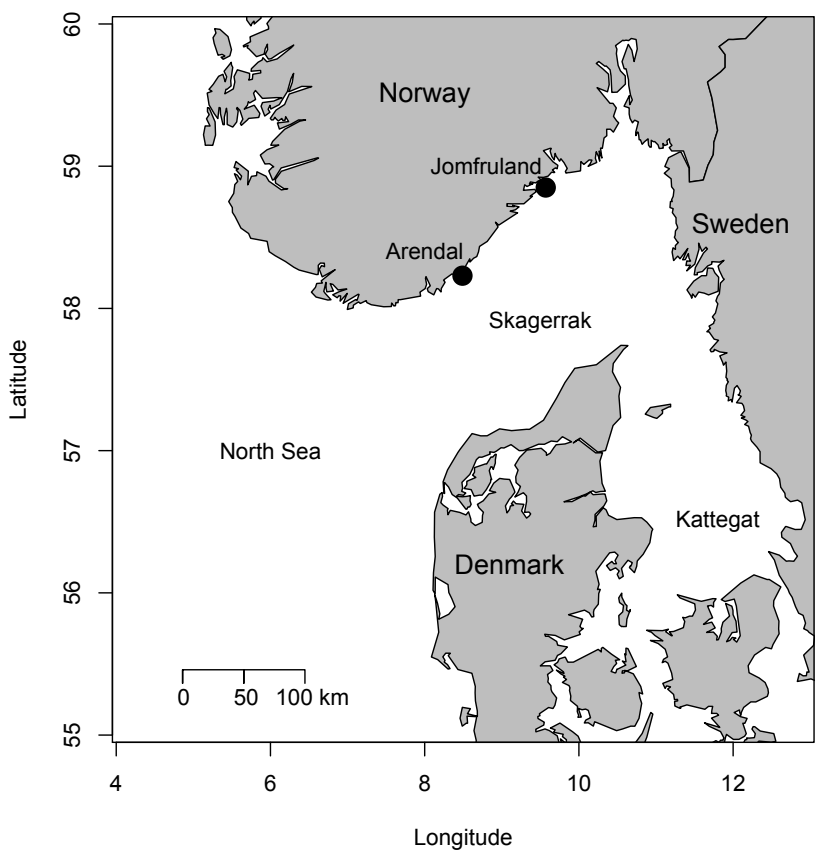

Fig. 1. Map of the Skagerrak with black dots showing monitoring stations Arendal and Jomfruland.

the inter-calibration results. An overview of analytical protocols used for the measured variables is given in Table 1.

Observations from the upper mixed layer $(\leq 10 \mathrm{~m}$; including sampling depths at 0,5 and $10 \mathrm{~m}$ for both stations) were analysed in this study. The numbers of observations were 1017 for POC and PON and 1009 for PP for Jomfruland and 1159 for all variables for Arendal. Nutrients, Chl- $a$ and seston concentrations and ratios were plotted with box-andwhisker plots (cf. Emerson and Strenio, 2000) in Figs. 2 to 4.

\subsection{Statistics}

All statistical analyses (including model fitting) and plotting in this work was done with the statistical software R (R Development Core Team, 2011). The C:N:P ratios (Fig. 4) were tested for significant deviations from the Redfield ratios by fitting a null model for the ratio (giving the overall mean), and investigating whether or not the Redfield ratio was included in the Confidence Intervals (CI). A Principal Component Analysis (PCA) with centred and unit variance scaled variables was performed on a selection of potential seasonal drivers for seston stoichiometry: temperature, salinity, Chl- $a$, DIN, DIP, TotN, TotP, and $\mathrm{SiO}_{2}$. The PCA was performed on combined data from both stations to increase the robustness of the analysis. The relationships between the two first PCA axes ( $\mathrm{PC} 1$ and $\mathrm{PC} 2$ ) of the drivers and the elemental ratios (C:N, C:P and N:P) was visualized in a biplot (Fig. 5). The driver vectors are determined by their loadings on the PCA axes, while elemental ratio vectors are positioned by their product-moment correlation coefficients with the PCA axes. The seasonal patterns of the two first PCA axes are shown in Fig. 6.

A Generalized Linear Model (GLM) from the Gamma family with an identity link function of POC, PON and PP to Chl- $a$ was used to investigate the composition of seston (Fig. 7). The dependent variable (POC) is then conditionally Gamma distributed with a constant coefficient of variation and with an expectation that depends linearly on the independent variable (Chl- $a$ ). The CI's of the regression lines in Figs. 7 and 8 were calculated from \pm 2 Standard Error (SE). A comparison of the amount of total deviance explained $\left(R^{2}\right)$ by the more traditional linear model of the log transformed POC, PON and PP on Chl- $a$ and by the GLM with Gamma distribution and identity link is shown in Table 3 . The pseudo $R^{2}$ for the GLM was calculated following Cameron and Windmeijer (1997).

To validate the GLM we compared estimates from the statistical model with estimates of phytoplankton $\mathrm{C}$ from the Arendal station (Fig. 8). The $20 \mathrm{yr}$ of observations were collapsed to a monthly scale, and the live-autotrophic percentage (converted from non-autotrophic percentage in Fig. 9) was plotted together with the percentage of phytoplankton $\mathrm{C}$ of seston POC concentrations. The phytoplankton $\mathrm{C}$ estimates were performed on samples from $5 \mathrm{~m}$, and carried out in accordance with Norwegian Standard 9429, using a Utermöhl sedimentation chamber and counting by use of an inverted microscope. Based on the phytoplankton quantifications, calculations of biovolume were carried out for each taxon using the best fitting geometric shape and matching equation. Phytoplankton $\mathrm{C}$ calculations were based on the calculated bio-volume, in accordance to Menden-Deuer and Lessard (2000).

The non-autotrophic percentage of total seston (Fig. 9) was calculated from the intercept of the regression line of POC on Chl- $a$ (from Fig. 7), divided by the mean POC concentration for all years. For the seasonal percentages the intercept of the regression line for the season was divided by the mean POC concentration of the corresponding season. The division into seasons was as follows: winter (December, January and February), spring (March, April and May), summer (June, July and August) and autumn (September, October and November). The ratios of C:N, C:P and N:P of the seston fractions (Figs. 10 and 11) was calculated as the ratio between slopes for the live autotrophic and ratio between intercepts for the non-autotrophic component of the regression of the relevant particulate organic element on Chl- $a$ (e.g. intercept POC/intercept PON for non-autotrophic C:N from Fig. 7). The SE of the ratios in Figs. 9 to 11 was calculated using first order variance propagation, with the simplified assumption that numerators and denominators are independent. The R package Ggplot2 was used to produce Figs. 9 to 11 (Wickham, 2009).

We explored the robustness of our estimates by a bootstrap analysis where the original data set was resampled 
Table 1. Overview of analytical protocols for Arendal and Jomfruland stations.

\begin{tabular}{|c|c|c|c|c|}
\hline & \multicolumn{2}{|l|}{ Arendal } & \multicolumn{2}{|l|}{ Jomfruland } \\
\hline & Instrument & Reference & Instrument & Reference \\
\hline $\begin{array}{l}\text { Salinity and } \\
\text { Temperature }\end{array}$ & $\begin{array}{l}\text { Neil Brun } \\
\text { CTD (Mark 111) }\end{array}$ & & $\begin{array}{l}\text { SEACAT CTD } \\
\text { (SEABIRD) }\end{array}$ & \\
\hline POC and PON & $\begin{array}{l}\text { Carlo Erba Elemental Analyzer } \\
\text { (M. 1106) }\end{array}$ & Ehrhardt (1983) & $\begin{array}{l}\text { Carlo Erba Elemental Analyzer } \\
\text { (M. 1106) }\end{array}$ & Ehrhardt (1983) \\
\hline $\mathrm{PP}$ & $\begin{array}{l}\text { Autoanalyzer (ALPKEM O. I. } \\
\text { analytical autoanalyzer) }\end{array}$ & $\begin{array}{l}\text { Valderrama (1981), } \\
\text { Hansen and } \\
\text { Koroleff (1999) }\end{array}$ & $\begin{array}{l}\text { Perkin-Elmer Optima } 4300 \text { DV } \\
\text { ICP-AES }\end{array}$ & ISO 11885 \\
\hline Chl- $a$ & $\begin{array}{l}\text { Turner Design Fluorometer } \\
\text { (M. 10). Calibrated by } \\
\text { Spectrophotometer (Shimadzu UV } \\
\text { 1201) }\end{array}$ & $\begin{array}{l}\text { Holm-Hansen et } \\
\text { al. (1965) } \\
\text { Jeffrey and } \\
\text { Humphrey (1975) }\end{array}$ & $\begin{array}{l}\text { Spectrophotometric detection } \\
\text { on Perkin-Elmer Lambda } 40 \mathrm{P} \\
\text { UV/VIS. }\end{array}$ & NS 4767 \\
\hline $\mathrm{NO}_{2}^{-}$and $\mathrm{NO}_{3-}$ & $\begin{array}{l}\text { Autoanalyzer (ALPKEM O. I. } \\
\text { analytical autoanalyzer) }\end{array}$ & $\begin{array}{l}\text { Benschneider and } \\
\text { Robinson (1952) }\end{array}$ & Skalar San Plus Autoanalyzer & NS 4745 \\
\hline $\mathrm{PO}_{4}^{3-}$ & $\begin{array}{l}\text { Autoanalyzer (ALPKEM O. I. } \\
\text { analytical autoanalyzer) }\end{array}$ & Grasshoff (1965) & Skalar San Plus Autoanalyzer & NS 4724 \\
\hline Tot $\mathrm{N}$ and Tot $\mathrm{P}$ & $\begin{array}{l}\text { Autoanalyzer (ALPKEM O. I. } \\
\text { analytical autoanalyzer) }\end{array}$ & Koroleff (1983) & Skalar San Plus Autoanalyzer & NS 4743 \\
\hline
\end{tabular}

with replacement 10000 times, and fitted linear-link gamma GLMs to particulate $\mathrm{C}, \mathrm{N}$, and $\mathrm{P}$ as function of chlorophyll for each resampled subset. The intercepts and slopes of the 3 GLMs from each resample were then used to compute corresponding estimates for $\mathrm{C}: \mathrm{P}, \mathrm{C}: \mathrm{N}$, and $\mathrm{N}: \mathrm{P}$ of nonautotrophs and autotrophs, respectively. The resulting bootstrap distributions of elemental ratios were visualized as kernel density estimates of their probability densities (Fig. 12), and compared for overlap between each other and with the Redfield ratios.

\section{Results}

\subsection{Seasonal variations in dissolved nutrients and seston concentrations}

The Arendal and Jomfruland stations are located in the Norwegian Coastal Current, about $80 \mathrm{~km}$ apart (cf. Fig. 1). In both stations there was a pronounced freshening in early spring and summer, with minimum salinity of 23 and 25, respectively, in late May and a steady increase during summer to the winter values of around 30 and 35, respectively, in December for Jomfruland and Arendal (data not shown). The brackish water mass in spring was caused mainly by freshwater input from local rivers with a larger relative influence at the Jomfruland station, and was usually constrained to the top $10 \mathrm{~m}$. The dominant water mass in the upper mixed layer the rest of the year was Skagerrak coastal water, which is mainly a mixture between waters from the North and Baltic Seas, surface water from Kattegat and local river water (Norderhaug et al., 2009). The concentrations of inorganic nutrients showed strong seasonal cycles at both stations with peak values in late winter close to $10,0.6$ and $10 \mu \mathrm{mol}^{-1}$ for DIN, DIP and $\mathrm{SiO}_{2}$, respectively (Fig. 2). All elements decreased markedly during spring and summer, with the lowest concentrations usually detected for DIP (notice the relatively high detection limit for DIP at the Jomfruland station). The spring blooms at both stations showed large inter-annual variability but generally peaked in March, and in some years an autumn bloom could be identified (Fig. 2).

Concentrations of POC, PON and PP increased by a factor of 2-3 from winter to summer (Fig. 3) with this increase being most pronounced for the Arendal station. This station displayed winter values below 10,1 and $0.1 \mu \mathrm{mol} \mathrm{l}^{-1}$ of POC, PON and PP, respectively, which more than doubled during the peak period. For Jomfruland a corresponding seasonal cycle was found for PP, but not for POC and PON. Here the background levels of POC and PON appear to be higher than at Arendal, such that concentrations remain high throughout the year except for slightly decreased concentrations in November and December.

While the fluctuations in dissolved nutrients covered an order of magnitude and the particulate fractions also showed more than a two-fold variability, covariation between POC, PON and PP yielded relatively stable seston elemental ratios (Fig. 4). The C:N ratio at the Arendal station was lower in spring and in late fall compared with winter and summer. It was significantly higher than the Redfield ratio of 6.6 (Table 2) and had an annual median of 7.8. The N:P and C:P ratios showed less seasonal variation, however the $\mathrm{C}: \mathrm{P}$ was also significantly higher that the Redfield ratio. The C:N ratio at the Jomfruland station showed less seasonal variation 

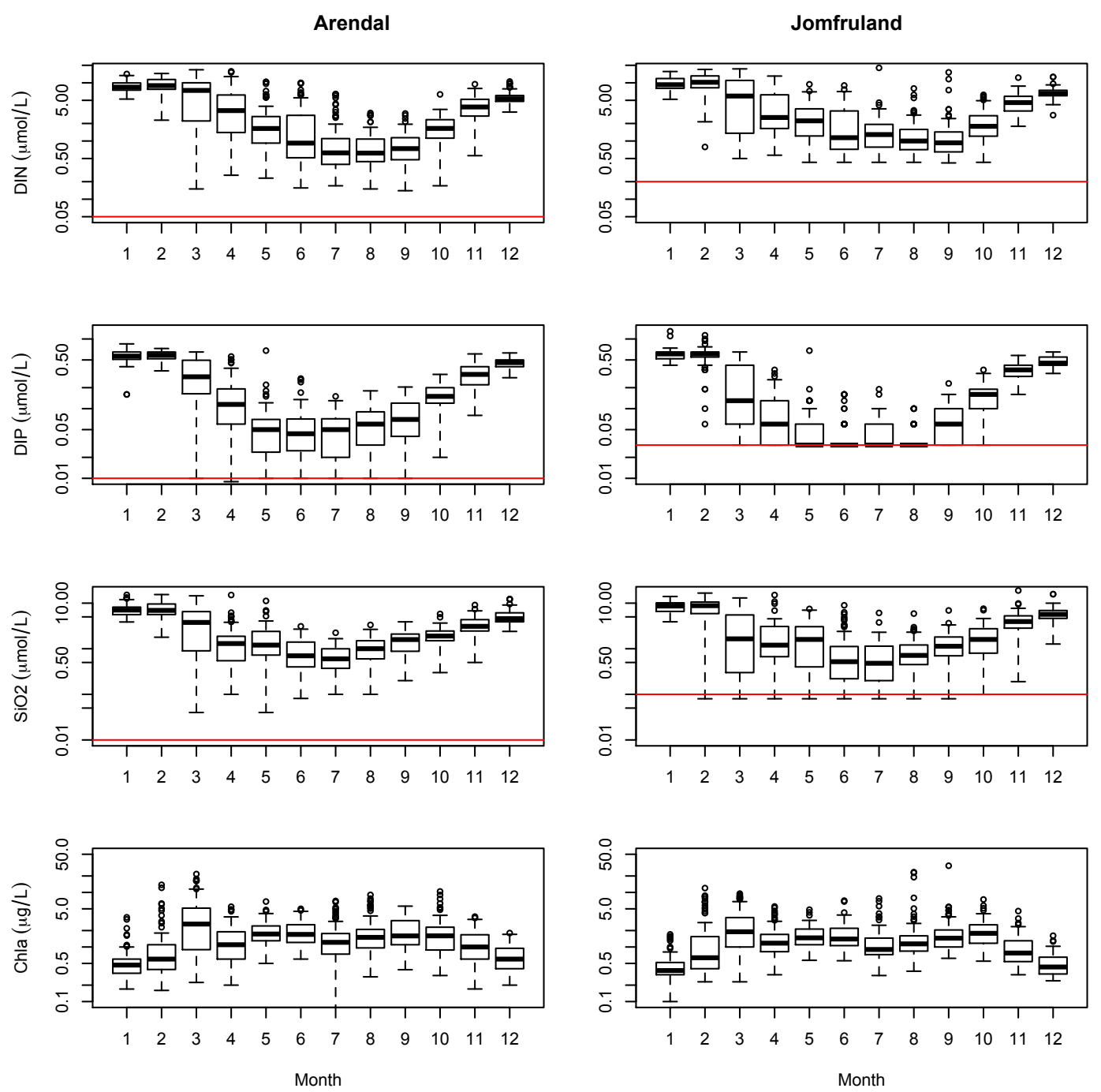

Fig. 2. Box-and-whisker plots showing the seasonal concentrations of DIN, DIP, $\mathrm{SiO}_{2}$ and Chl- $a$ at Arendal and Jomfruland. The nutrient concentrations are in $\mu \mathrm{mol} 1^{-1}$ and Chl- $a$ in $\mu \mathrm{g} 1^{-1}$. The y-axes are log-scaled, and the detection limits for the nutrients are indicated with red horizontal lines.

than at the Arendal station and was closer to the Redfield ratio (annual median 6.7), however it was also significantly higher than the Redfield ratio. The N:P and C:P ratios at Jomfruland were significantly higher than the Redfield ratio and were especially high during winter months.

\subsection{Ordination of seasonal drivers}

The first two axes in the PCA ordination of seasonal drivers (Fig. 5) accounted for $69 \%$ of the total variation. The scores for the two stations overlapped, indicating that they were both reflecting the same environmental gradients. Chl- $a$, TotN, and salinity were oriented along PC2, while temperature and the nutrient concentrations were along PC1. The vectors for $\mathrm{C}: \mathrm{P}$ and $\mathrm{N}: \mathrm{P}$ were identical and both $\mathrm{PC}$ axes were equally important in describing the variation in these ratios.
The figure shows that increased $\mathrm{C}: \mathrm{P}$ and $\mathrm{N}: \mathrm{P}$ ratios were related to higher nutrient concentrations (especially TotN, DIN and $\mathrm{SiO}_{2}$ ) and lower temperatures. The $\mathrm{C}: \mathrm{N}$ ratios were oriented along $\mathrm{PC} 2$, with higher $\mathrm{C}: \mathrm{N}$ ratios at higher salinities and lower Chl- $a$ and TotN concentrations. There was a clustering of the seasons along PC1, and the strong seasonal component in this axis was illustrated by plotting the PCs against month (Fig. 6).

\subsection{Composition of seston}

The regressions of POC, PON and PP with Chl- $a$ as the independent variable are shown in Fig. 7. The estimated percentage of phytoplankton $\mathrm{C}$ was compared to the percentage of live autotrophs from the statistical model (Fig. 8). The two independent estimates of autotrophic contribution to 

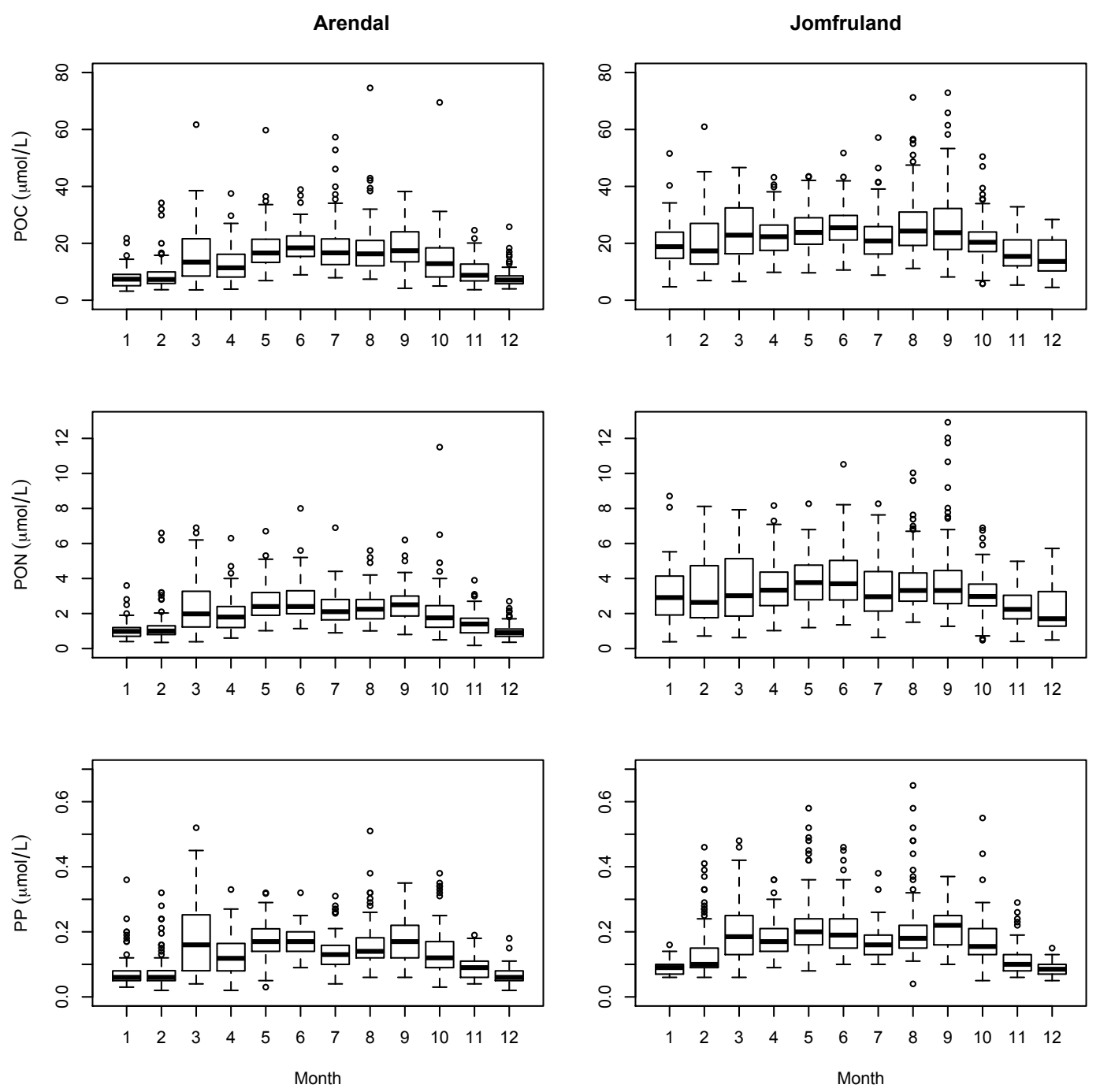

Fig. 3. Box-and-whisker plots showing the seasonal concentrations of POC, PON and PP at Arendal and Jomfruland. All concentrations are in $\mu \mathrm{mol} 1^{-1}$.

total seston ranged between 10 and $50 \%$ and showed overall good correspondence and similar seasonal signals, with more autotrophs in summer than in winter. The statistical model predicts a low autotrophic percentage in June, in contrast to the estimated phytoplankton C. It also appears that the statistical model underestimates the percentage of autotrophs in late winter and spring, while it overestimates the autotrophic percentage in late fall. The estimated annual mean fraction of seston POC not associated with Chl- $a$ (Fig. 9), i.e. the non-autotrophic fraction, was $76 \%$ and $55 \%$ for the Jomfruland and Arendal stations, respectively. When looking at the seasonal pools of non-autotrophic seston the Arendal station appeared to have a seasonal cycle with the highest fraction in winter and lowest in autumn. While at the Jomfruland station the fraction of non-autotrophic seston was also highest in winter, but stayed high throughout the year. For both stations the elemental ratios were, in general, lower in the live autotrophic (Fig. 10) than in the non-autotrophic (Fig. 11) fraction of seston. For the Arendal station the C:N and C:P ratios of live autotrophs were higher in summer and autumn compared to winter and spring, while the elemental ratios in the non-autotrophic fraction did not show large seasonal variations. At the Jomfruland station, the $\mathrm{C}: \mathrm{N}$ ratios were similar between the live autotrophic (Fig. 10) and the nonautotrophic (Fig. 11) fractions. However, the C:P and N:P ratios were almost a factor of 3 higher in non-autotrophs. The difference in elemental ratios between the two fractions is manly governed by the $\mathrm{P}$ content, which is illustrated by the high $\mathrm{N}: \mathrm{P}$ and $\mathrm{C}: \mathrm{P}$ ratios of the non-autotrophic fractions in Fig. 12. For both stations the live autotrophic N:P and $\mathrm{C}: \mathrm{P}$ ratios were significantly lower than Redfield, while the non-autotrophic ratios were significantly higher for both 

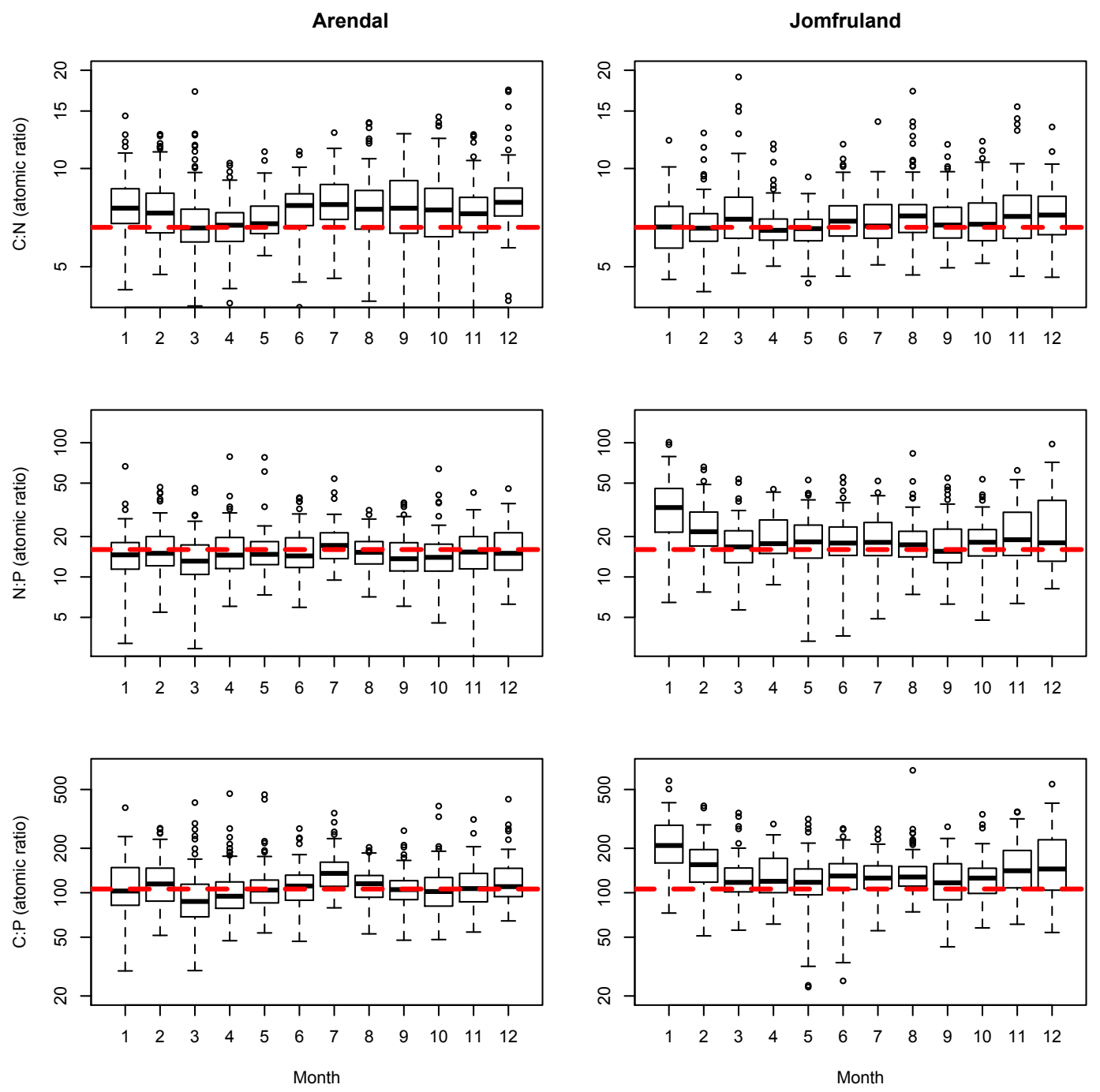

Fig. 4. Box-and-whisker plots showing the seasonal ratios of $C: N, N: P$ and $C: P$ (atomic ratios) for Arendal and Jomfruland. Dashed red lines show Redfield ratios and the y-axes are log-scaled.

Table 2. Confidence Intervals (CI) of null model (overall mean) of $\mathrm{C}: \mathrm{N}, \mathrm{C}: \mathrm{P}$ and $\mathrm{N}: \mathrm{P}$. The $\mathrm{C}: \mathrm{N}: \mathrm{P}$ ratio is deemed as significantly different from the Redfield ratio if the respective Redfield ratio is not included in the CI.

\begin{tabular}{llrrrrr}
\hline & & \multicolumn{2}{c}{ Arendal } & & \multicolumn{2}{c}{ Jomfruland } \\
\cline { 3 - 4 } \cline { 6 - 7 } & Redfield & $2.5 \%$ & $97.5 \%$ & & $2.5 \%$ & $97.5 \%$ \\
\hline $\mathrm{C}: \mathrm{N}$ & 6.6 & 7.4 & 7.7 & & 6.9 & 7.2 \\
$\mathrm{C}: \mathrm{P}$ & 106 & 113.6 & 119.2 & & 139.1 & 147.1 \\
$\mathrm{~N}: \mathrm{P}$ & 16 & 15.7 & 16.5 & & 20.7 & 22.1 \\
\hline
\end{tabular}

stations. The $\mathrm{C}: \mathrm{N}$ ratios at the two stations were not significantly different between the two fractions, and only the nonautotrophic $\mathrm{C}: \mathrm{N}$ ratio at the Arendal station was significantly higher than Redfield.

\section{Discussion}

\subsection{Environmental factors controlling seston stoichiometry}

Seasonal variations in seston elemental ratios are driven by processes such as nutrient depletion (Körtzinger et al., 2001; Koeve, 2004; Bates et al., 2005), changes in light and mixed layer depth (Huisman et al., 1999; Omta et al., 2006), phytoplankton species composition (Quigg et al., 2003) and variable contributions of autotrophs, heterotrophs and detritus (Hessen et al., 2003). In the ordination of seasonal drivers (temperature, salinity, Chl- $a$ and nutrient concentrations) the two monitored stations displayed a rather consistent pattern with regard to seston stoichiometry. The PC1 axis captured most of the seasonal variation, representing changes in temperature and inorganic nutrients (and probably light intensity, 


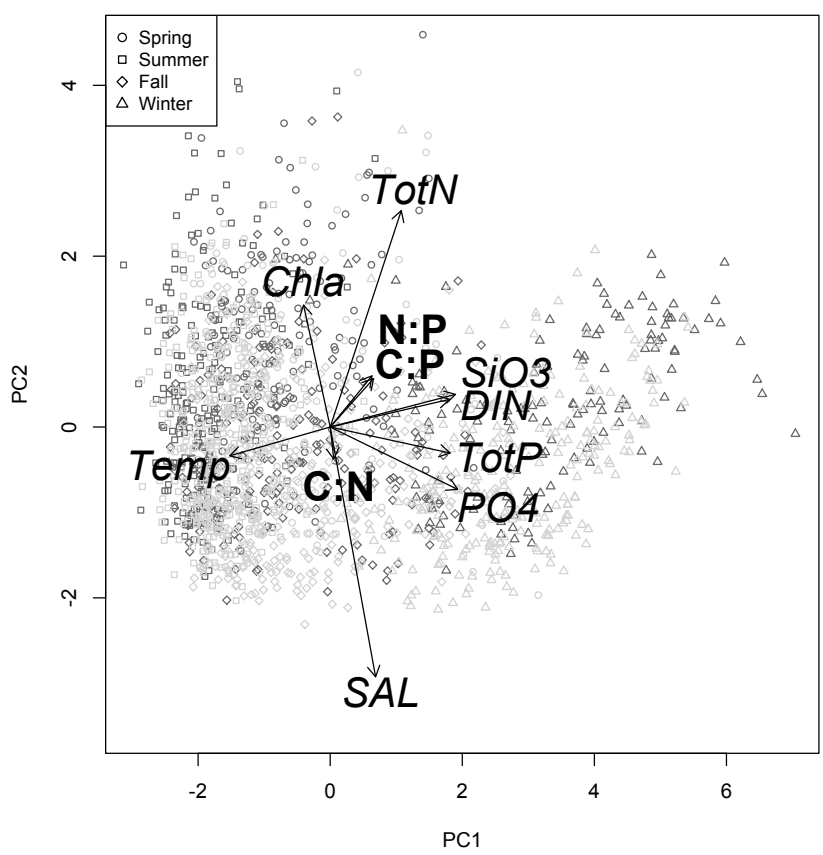

Fig. 5. Biplot of PC1 vs. PC2 of seasonal drivers for Arendal (light grey) and Jomfruland (grey). Arrows show the loadings of the seasonal drivers (italics) and the correlation between elemental ratios and the PC axis (bold). See methods for detailed explanation.
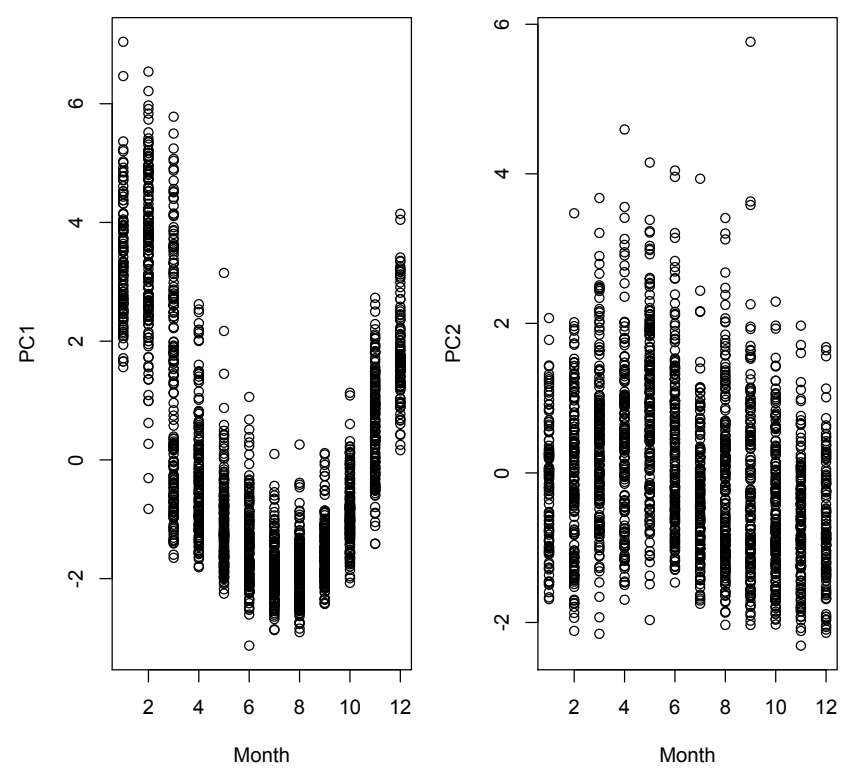

Fig. 6. Plot of PC1 (left) and PC2 (right) vs. month of the year.

yet PAR was not included), which could be seen in the predictable monthly pattern of this axis in Fig. 6. The PC2 axis was more related to inter-annually varying phenomena, and salinity indicates that watermass characteristics, the input of freshwater and stratification were the dominant driving processes. In addition Chl- $a$ fell along this axis, which indicates that the timing of the spring bloom and the level of productivity are important drivers. Tot $\mathrm{N}$ and salinity pointed in opposite directions, indicating that $\mathrm{N}$ to a large degree comes from riverine inputs, probably in the form of DON, which is not directly bioavailable. The orientation of $\mathrm{C}: \mathrm{N}$ along the PC2 axis showed that the water mass characteristics and bloom dynamics were the most important drivers affecting this relationship. The $\mathrm{C}: \mathrm{N}$ ratio increased with salinities, indicating higher $\mathrm{C}: \mathrm{N}$ in summer, when there is a stronger Atlantic influence. There was a negative correlation with Chl- $a$, and periods with high Chl- $a$, such as the spring and fall bloom, were related to slightly lower $\mathrm{C}: \mathrm{N}$ ratios.

The overlap of the vectors for C:P and $\mathrm{N}: \mathrm{P}$ indicated that these ratios were driven by the same processes through the production and degradation of PP. The orientation showed an equal contribution of both $\mathrm{PC}$ axes with strongest correlation to the nutrient concentrations and Chl- $a$. Therefore the natural variation in the $\mathrm{C}: \mathrm{P}$ and $\mathrm{N}: \mathrm{P}$ ratios were mainly driven by changes in nutrient concentrations and biomass, with higher ratios at lower temperatures and salinities and high TotN concentration. These conditions are characteristics for the winter period, and reflects the increased $\mathrm{C}: \mathrm{N}$ and $\mathrm{C}: \mathrm{P}$ in winter in Jomfruland, which also represents the largest gradients in these ratios (cf. Fig. 4).

\subsection{Seasonal variation in seston concentrations and ratios}

There were year-round high levels of POC and PON at the Jomfruland station, which has been attributed to advected organic material and local supply from the nearby Frierfjord (Norderhaug et al., 2009). Even though the POC concentration was high, the annual median $\mathrm{C}: \mathrm{N}$ at this station was 6.7, because PON was tightly coupled to POC. The low Chl- $a$ concentration, high POC:Chl- $a$ ratio (data not shown) and a correspondingly high percentage of non-autotrophic material (76\%, Fig. 9) gave the somewhat counterintuitive situation that the C:N relationship was close to Redfield year-round (cf. Fig. 4), even though only a minor fraction of the particulate matter was phytoplankton. Both C:P and N:P showed an increase in winter at Jomfruland, because the PP concentration decreased markedly from November to February.

The annual median C:N at the Arendal station was 7.8, even though it had the highest calculated live autotrophic contribution (45\%, Fig. 9) of the two stations. There was a trend in $\mathrm{C}: \mathrm{N}$ over season (cf. Fig. 4), with lower $\mathrm{C}: \mathrm{N}$ in spring relative to later in the productive season and winter. Körtzinger et al. (2001) showed that the C: $\mathrm{N}$ ratios of seston increased from around 5 in an early-bloom to around 7 in a post-bloom situation in the northeast Atlantic Ocean. This seasonal uncoupling of the C:N ratio has been termed "carbon overconsumption" (Toggweiler, 1993) and has also been demonstrated in the nutrient depleted summer waters of the Norwegian shelf (Falck and Anderson, 2005). This process could be observed in the seston C:N in Arendal which 

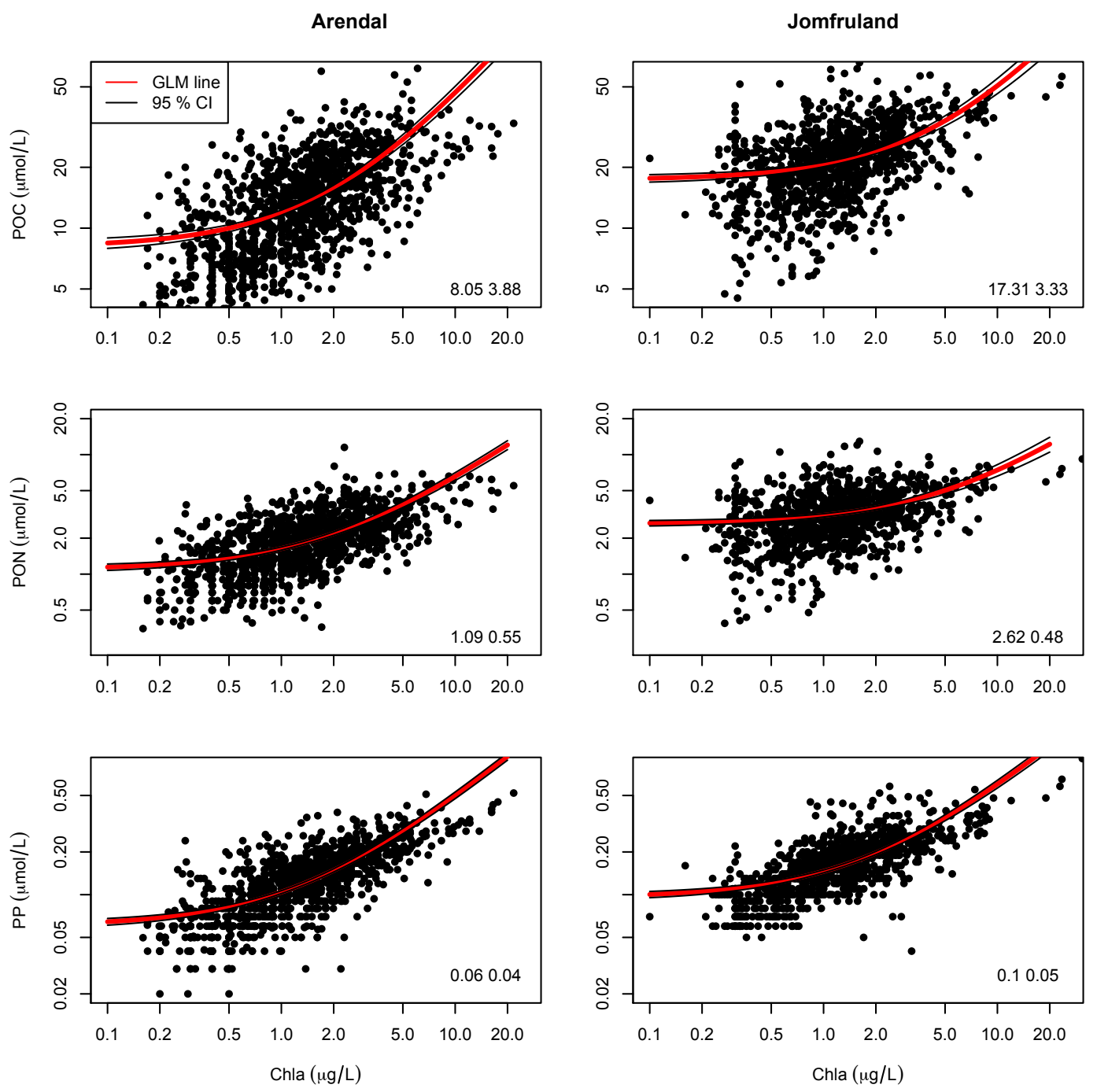

Fig. 7. Panel with POC, PON and PP vs. Chl- $a$ for Arendal and Jomfruland with regression line (GLM with Gamma distribution and identity link) and upper and lower $95 \%$ CI. Intercept and slope of the regression lines are shown in the right corner. The seston concentrations are in $\mu \mathrm{mol} 1^{-1}$ and Chl- $a$ in $\mu g 1^{-1}$. Please note that the $\mathrm{x}$ and $\mathrm{y}$-axes are log-scaled (not the data).

increased from a median of 6.6 in March to 7.6 in August. The overall small seasonal deviations from the Redfield ratio commonly encountered in marine seston could be interpreted as if the planktonic autotrophs grow under a "balanced" supply of nutrients, and deviations from Redfield ratio has commonly been used as an indicator of nutrient limitation (Goldman et al., 1979). However, the seasonal drawdown of inorganic nutrients in this study (and numerous others) under (nearly) stable seston stoichiometry does not support this view (cf. Fig. 2). On the contrary, Ptacnik et al. (2010) found seston $\mathrm{N}: \mathrm{P}$ to be the poorest, among a suite of indicators, to predict nutrient limitation, which at least in part is explained by the mixed nature of seston composition. Phytoplankton does not obey homeostatic rules in their elemental household, but rather show, at least in cultures, strong variability in their $\mathrm{C}: \mathrm{P}$ and $\mathrm{N}: \mathrm{P}$ (less for $\mathrm{C}: \mathrm{N}$ ) ratios depending on growth conditions (cf. Geider and La Roche, 2002; Sterner and Elser, 2002). Hence we suggest that the stability in the elemental ratios in mixed communities may not necessarily reflect balanced growth. Rather, we propose that this stability reflect variable proportions of sestonic fractions over the season.

\subsection{Statistical disentangling of seston composition}

There is no standardized method for determining the functional composition of seston and the fractions of POC, PON and PP associated with phytoplankton, therefore any such information has to be obtained by indirect means. Using a regression model of POC on Chl- $a$ to separate the autotrophic and non-autotrophic fractions of seston has been applied in several studies (Steele and Baird, 1961, 1965; Tett 

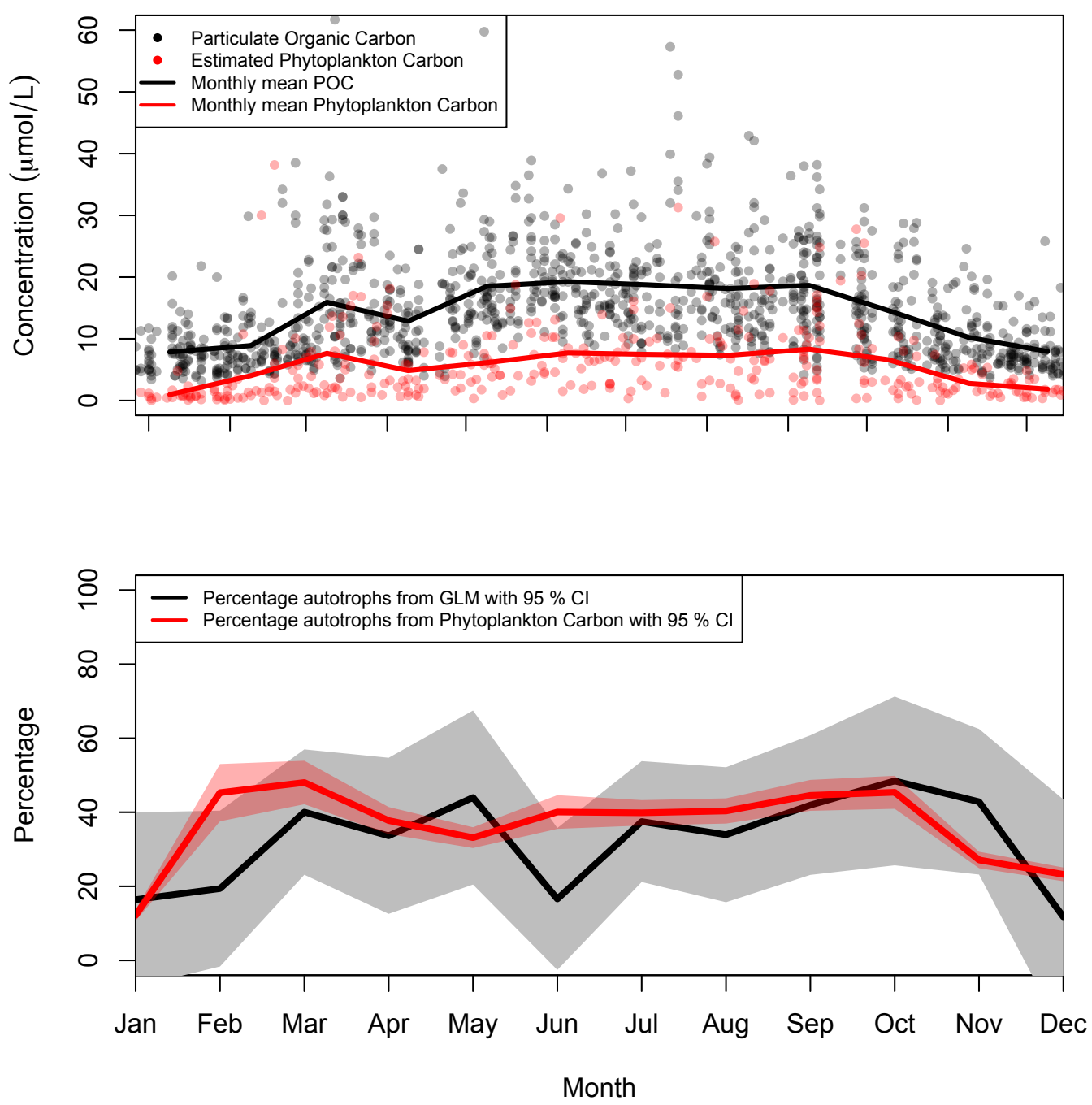

Fig. 8. Upper panel shows the seasonal concentrations of POC and phytoplankton $\mathrm{C}$ in $\mu \mathrm{mol} 1^{-1}$, while the lower panel shows the independent estimates of autotrophic percentage from phytoplankton $\mathrm{C}$ and the regression model.

et al., 1975; Eppley et al., 1992), to derive the phytoplankton biomass and growth rate, and estimate the proportion of non-algal matter. The accuracy of this kind of regressionbased estimates has been disputed, however, since the sestonic fractions (detritus, zooplankton and phytoplankton) do not vary independently of one another (Banse, 1974, 1977; Pissierssens et al., 1985). Previous studies has, however, shown a good fit of the regression model compared to other estimates (e.g. Eppley et al., 1992). Seston data are often heteroscedastic, and the standard remedy is to log-transform the samples, however this procedure changes the interpretation of the regression coefficients. In this study we therefore use a Generalized Linear Model (GLM) from the Gamma family with an identity link function. The GLM regression line of the seston concentration on Chl- $a$ (Fig. 7) was interpreted such that the intercept on the y-axis (e.g. POC when [Chl$a]=0$ ) was the non-autotrophic component of the seston. It is important to note that the use of this term does not imply that the material cannot have an autotrophic origin, since it will include recently dead phytoplankton (where Chl- $a$ has decomposed), bacteria and other small heterotrophs, as well as detritus of both allochthonous and autochthonous origin. The slope of the regression line was interpreted as the seston POC, PON or PP to Chl- $a$ ratio of the live autotrophic component (for more explanation of calculations underlying Figs. 9 to 11, see Sect. 2.3). The term live autotrophic was used to emphasize that only material containing Chl- $a$ will be included in this fraction, while it will not include recently dead organisms where the Chl- $a$ has degraded to phaeopigment. An similar approach for separating sestonic fractions with a GLM has previously been applied to lakes (Hessen et al., 2003), and in this study we test the applicability for marine waters (Fig. 8). The obvious limitation of the regression model is the variability of the POC:Chl- $a$ ratio with light, 


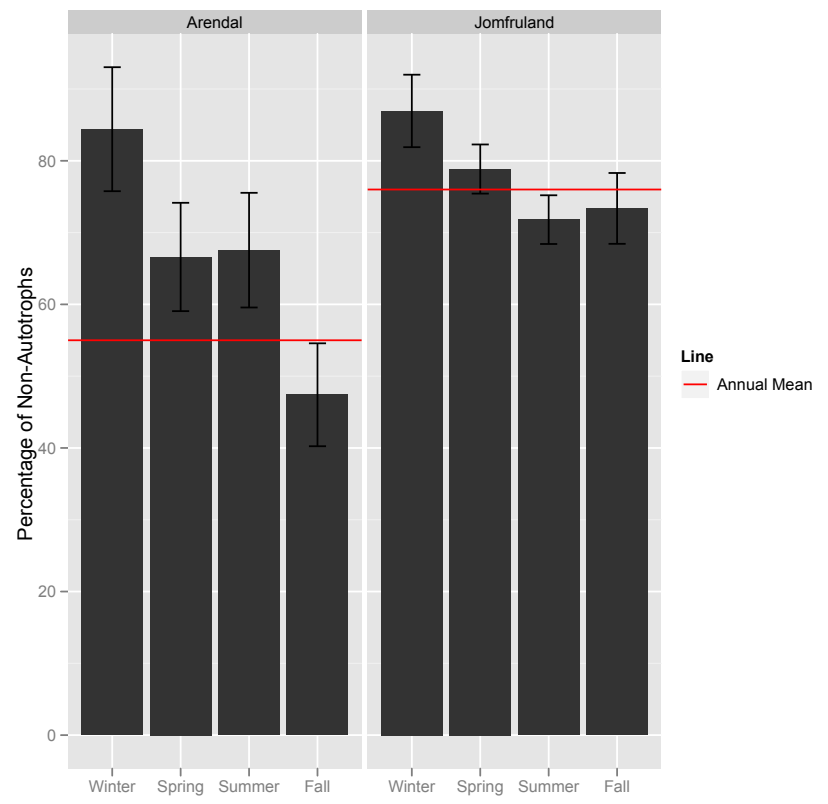

Fig. 9. Calculated non-autotrophic percentage of total seston from regression model for Arendal and Jomfruland, with annual mean percentage and error bars showing the SE.

and therefore also depth, and between species and growth strategy (i.e. autotrophic vs. mixotrophic). As mentioned, this method assumes that phytoplankton $C$ does not covary with detrital or zooplankton C (e.g. Banse, 1977). We have divided the data into seasons to limit the errors introduced by these correlations, however this assumption is admittedly disputable. Fitting the regression models for each season allows the POM:Chl- $a$ ratios to vary, and there is indeed different slopes and intercepts for POM vs. Chl- $a$ throughout the year, which is illustrated in the different estimates for different seasons in Figs. 9-11. Therefore this procedure is also a test of the ability of the regression model to reproduce the trends that we expect in autotrophic percentage and elemental ratios of sestonic fractions. An expectation would be that the share of phytoplankton in seston is higher during the productive season, and lower in winter when the nonautotrophic fraction is higher. This is what we estimate with the regression model in Fig. 9 for Arendal, while for Jomfruland there is no seasonal signal in autotrophic percentage, which is attributed to an allochthonous source of suspended matter (as also discussed elsewhere). In general for the live autotrophs (Fig. 10) we see that the C:nutrient increases over the productive period, as has been shown in the literature due to "carbon overconsumption". In addition we see in Fig. 11 that the C:nutrient is higher in the non-autotrophic fraction than the live autotrophic fraction, as would be expected from preferential remineralization.

Given the assumptions inherent in the method, we compared the estimates of autotrophic percentage from the model with data of phytoplankton carbon (from microscopic counts
Table 3. Comparison of pseudo $R^{2}$ for GLM and $R^{2}$ for log-linear regression models of POC, PON and PP on Chl- $a$ (se methods for description of calculations).

\begin{tabular}{lrrrrr}
\hline & \multicolumn{2}{c}{ Arendal } & & \multicolumn{2}{c}{ Jomfruland } \\
\cline { 2 - 3 } \cline { 6 - 6 } & Glm & Lm $(\log )$ & & Glm & \multicolumn{2}{c}{ Lm (log) } \\
\hline POC & 0.37 & 0.39 & & 0.22 & 0.23 \\
PON & 0.38 & 0.40 & & 0.15 & 0.18 \\
PP & 0.57 & 0.59 & & 0.50 & 0.54 \\
\hline
\end{tabular}

and biovolume conversions) taken for the Arendal stations over the 20 -yr period. The two independent estimates of autotrophic percentage of total seston display reasonable correspondence (Fig. 8), and there is a seasonal cycle with highest percentage in the productive season (especially during the spring and fall blooms) and less in the winter months. However the regression model predicted a lower autotrophic percentage in June relative to the estimate of phytoplankton C based on cell counting. This was caused by a high POC:Chl$a$ intercept in the regression, which could be related to the post-bloom build-up of zooplankton biomass (which will be included in the non-autotrophic fraction) frequently recorded in June for this station (Norderhaug et al., 2009). The discrepancies between the two estimates could therefore result from the failure of the statistical model to efficiently capture the reversal of growth trends of the sestonic fractions, for example at the decline of a bloom when the phytoplankton $\mathrm{C}$ starts decreasing while the zooplankton and detrital $\mathrm{C}$ continues to increase (cf. "third error source" in Banse, 1977). The GLM had comparable $R^{2}$ to the traditional method using a log-linear model (Table 3 ), but with the added benefit that the parameter estimates (intercept and slope) are biologically meaningful quantities.

\subsection{Seston composition and contribution from live autotrophs}

At both stations the annual mean phytoplankton percentage of total seston was less than $50 \%$ (Fig. 9). The fraction of live autotrophs ranged from around 20 to $60 \%$ for Arendal, while only from 10 to $30 \%$ for the Jomfruland station. A survey of lake data suggested that autotrophs indeed are minor components of seston, rarely accounting for more that $25 \%$ of seston $\mathrm{C}$, but in spite of this no strong deviations from Redfield was detected (Hessen et al., 2003). Marine environments are commonly expected to have a smaller contribution of non-autotrophic seston, partly due to less impact from allochthonous inputs, yet there are a range of studies based on different methods that suggest a major contribution on non-autotrophic seston. E.g. the autotrophic percentage of seston ranged between 20-95\% for studies based on the regression model approach (Wienke and Cloern, 1987; Eppley et al., 1992), 20-60\% for studies based on phytoplankton 


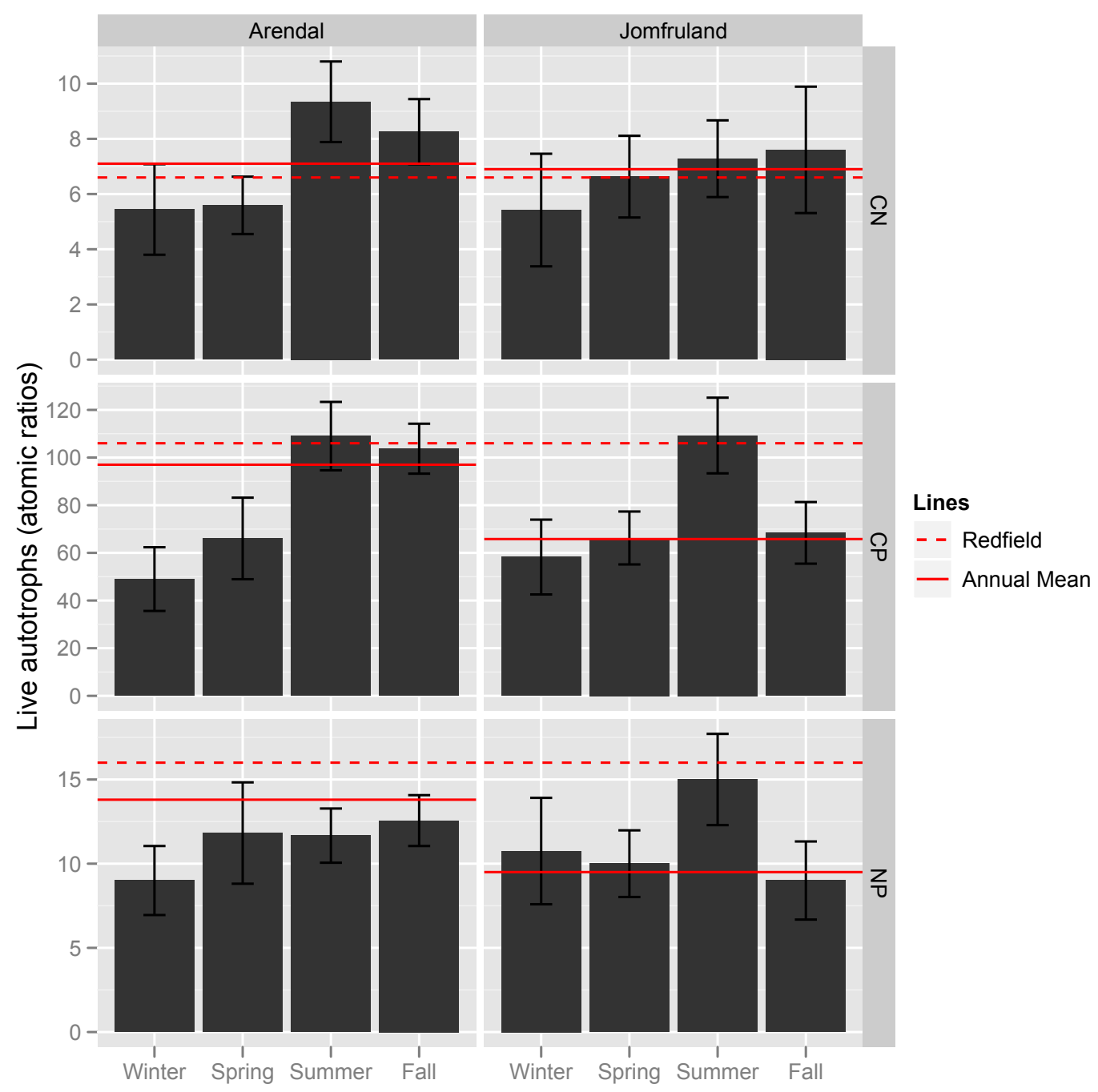

Fig. 10. Calculated $C: N, C: P$ and $N: P$ of live autotrophs for Arendal and Jomfruland from regression model, with lines showing annual mean ratio and the Redfield ratios. Error bars show the SE.

microscopy (DuRand et al., 2001; Gundersen et al., 2001) and 19-21\% for satellite derived estimations (Oubelkheir et al., 2005), covering a wide range of ocean regions and productivity levels.

\subsection{Elemental ratios of live autotrophic and non-autotrophic fractions}

Seston is a heterogeneous mix of particulate matter, and includes a range of autotrophic and heterotrophic species plus a detrital component of mixed origin, which may vary substantially in their elemental compositions. For example, there is a higher cell-specific content of $\mathrm{P}$ (and to some extent $\mathrm{N}$ ) in heterotrophic bacteria (cf. Vadstein, 2000) and zooplankton (Andersen and Hessen, 1991; Sterner and Elser, 2002) compared with autotrophs. A high fraction of these heterotrophic components may thus yield decreased $\mathrm{C}: \mathrm{P}$ or $\mathrm{C}: \mathrm{N}$ ratios.
However, recent studies have shown that freshwater bacteria might be more stoichiometrically flexible than previously assumed, and might have a nutrient composition similar to seston as a whole (Cotner et al., 2010). On the other hand, a high share of detritus would give increased $\mathrm{C}: \mathrm{P}$ and $\mathrm{N}: \mathrm{P}$ ratios, since detrital particles generally are deprived of nutrients (Sterner and Elser, 2002; Hessen et al., 2003). Many studies have shown a preferential remineralization of nutrients (especially P) over carbon (Menzel and Ryther, 1964; Li et al., 2000; Osterroht and Thomas, 2000; Thomas, 2002), which would lead to higher $\mathrm{C}$ :nutrient ratios in the detritus (and thereby the non-autotrophic fraction) than in the live autotrophic fraction. The method applied in our study allows for estimates not only of the fraction of autotrophs of total seston mass as discussed above, but also of elemental ratios in the autotroph and non-autotroph fractions. For these estimates we do not have observational data in order 


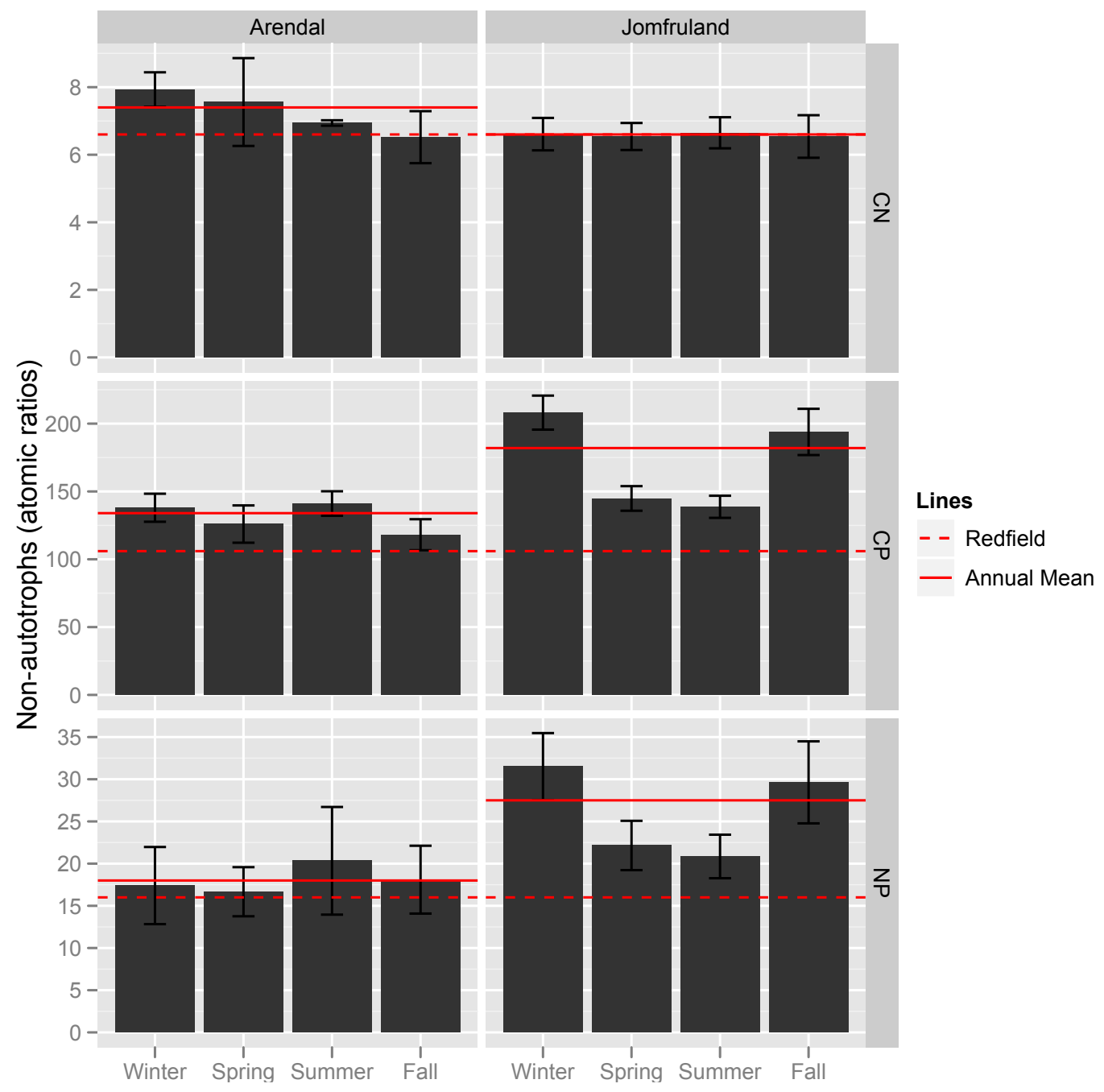

Fig. 11. Calculated $C: N, C: P$ and $N: P$ of non-autotrophic fraction for Arendal and Jomfruland from regression model, with lines showing annual mean ratio and the Redfield ratios. Error bars show the SE.

to validate the results of the regression model. The results from Fig. 8, and the fact that the elemental ratios shown in Figs. 10 and 11 reproduce the expected signals, gives confidence that the overall trends in these estimates are correct. However, these figures should nevertheless be judged with some caution and probably reflect general trends more than accurate numbers in the elemental ratios of the sestonic fractions for the two stations. The estimated $\mathrm{C}$ :nutrient ratios of live autotrophs were in general lower than Redfield, while the non-autotrophic $C$ :nutrient ratios were higher than the live autotrophic ratios and above or close to the Redfield ratio. For the Arendal station the increase in $\mathrm{C}$ :nutrient ratios from the live autotrophic to non-autotrophic fraction was less pronounced. This station had a higher percentage of live autotrophs, which could result in the "reversed causality" between seston and phytoplankton biomass found by Hessen et al. (2003). In this case the living phytoplankton cells were an important source of the detritus, and consequently some of the "stoichiometric footprint" of the phytoplankton may be retained (for some time) and thus influence the elemental composition of seston as a whole. The higher C:P and $\mathrm{N}: \mathrm{P}$ of the non-autotrophic compared to the live autotrophic fraction at Jomfruland suggests that detritus is a substantial component in this pool, because of the abovementioned high influence from local river run-off for this station.

\subsection{Implications of seston composition for food quality}

Particulate organic matter is the base of the pelagic food web, and it is well known that it is not only the quantity (in terms of $\mathrm{C}$ ), but also the quality (measured as the ratio of $\mathrm{C}$ to nutrients) that is important for pelagic grazers, since the supply of $\mathrm{N}$ and $\mathrm{P}$ through the food can be less than the heterotrophic demand for growth (Hessen, 2008). While N may be the limiting element for egg-production in copepods (cf. Kiorboe, 1989; Anderson and Hessen, 1995), P could also constitute 

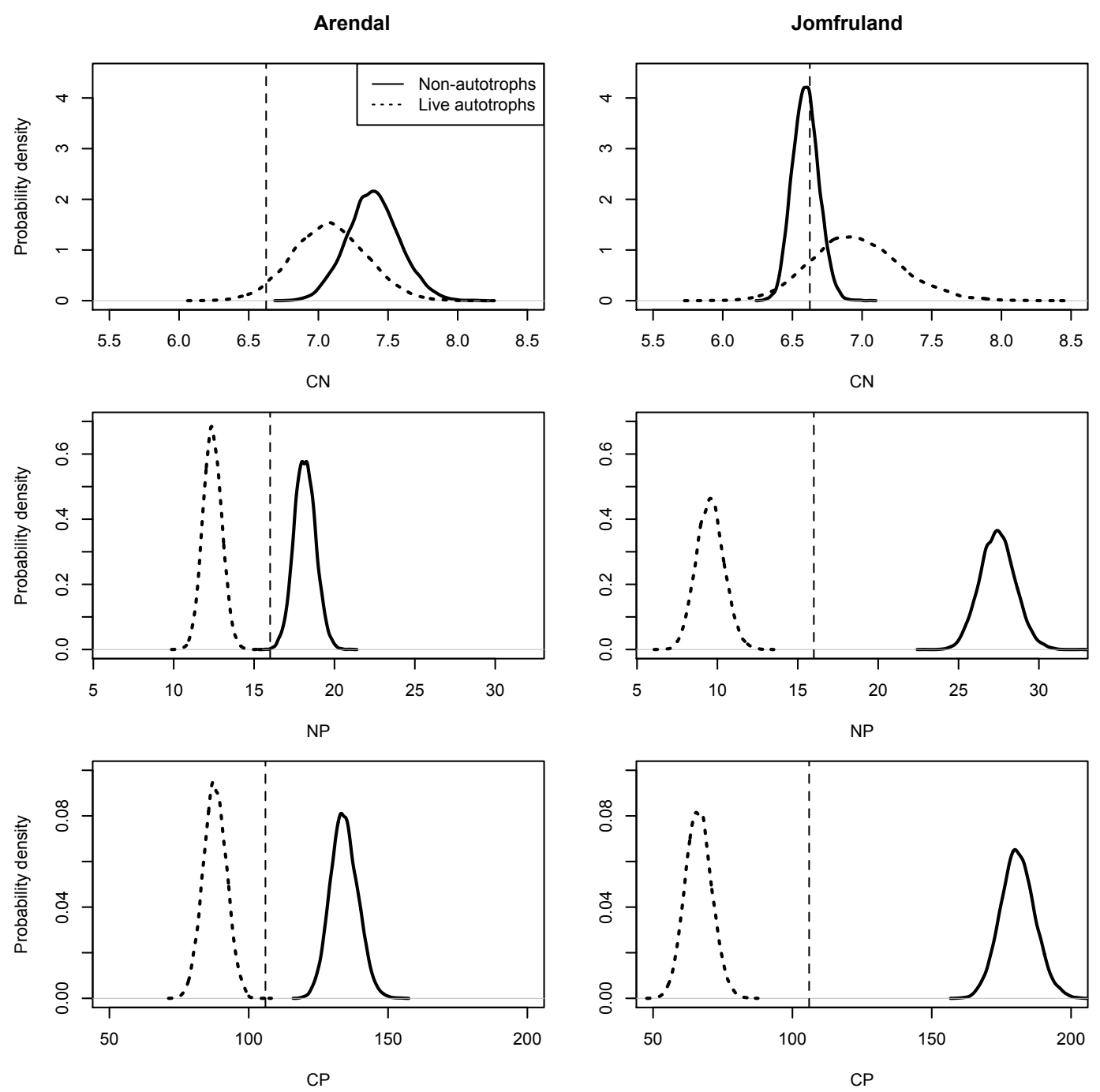

Fig. 12. Probability densities of $C: N, C: P$ and $N: P$ for the live autotrophic and non-autotrophic fractions calculated with the regression model, for information on bootstrapping procedures see Sect. 2.3. The stippled vertical lines indicate the Redfield ratios.

a stoichiometric bottleneck at the nauplius stage due to their high P-demands for ribosomal RNA during periods of peak growth. Generally, $\mathrm{N}$ and $\mathrm{P}$ are important for consumers in active growth, while they are considered less important in maintenance metabolism (Hessen, 2008). Hence knowledge about the seston composition is imperative to assess the flux of energy and matter from seston to higher trophic levels.

\subsection{Variable sestonic composition may stabilize elemental ratios}

An established notion in the field of ecological stoichiometry is that suspended particulate matter is a reliable indicator of the composition of bulk autotroph biomass (Sterner and Elser, 2002). However, phytoplankton frequently constitute a modest share of seston mass as a whole, and the other major contributors to seston, detritus and heterotrophic organisms, may have contrasting C:nutrients ratios. Often phytoplankton are modeled as an organic pool of $\mathrm{N}$ or $\mathrm{P}$ (cf. Weber and Deutsch, 2010), which is interpreted as consisting solely of phytoplankton. While this approach might be a sufficient approximation for highly productive areas of the open ocean it may reveal important stoichiometric processes in phytoplankton and other sestonic fractions in the coastal ocean. The relatively stable seasonal patterns in seston elemental ratios observed in this study do not contradict variable stoichiometry in phytoplankton, precisely because phytoplankton responses can be masked by other sestonic fractions. We suggest that both elemental ratios close to Redfield, as well as departures from Redfield, in many cases should not be accredited a balance between nutrient supply and demand in autotrophs, but rather an effect of a balance between sestonic fractions. The sestonic fractions 
have different stoichiometric composition, and the seston ratios as expressed in Fig. 4, was a result of the relative contributions of these fractions with contrasting C:nutrient relationships. For example, an increased share of heterotrophs (with low C:P) could "compensate" for a high share of detritus (high $\mathrm{C}: \mathrm{P}$ ) in a post-bloom situation. Resulting in what could be described as "the right answer but for wrong reasons". This idea of balancing sestonic fractions giving an apparently Redfieldian stability has parallels to Klausmeier et al. (2004), where it was shown that the Redfield N:P ratio of 16 represented the average conditions of relative contributions of phytoplankton growth types with contrasting $\mathrm{N}: \mathrm{P}$ ratios.

Our data is in support of Marañon (2005), who based on studies of phytoplankton growth rates in the subtropical areas of the north Atlantic, concluded that the frequent observation of seston C:N-ratios close to Redfield even in situations with slow growing, nutrient limited phytoplankton could be accredited bacterial and detrital contributions to seston. One should therefore be careful in interpreting sestonic $\mathrm{C}: \mathrm{N}$-ratios as indicators of nutritional status of phytoplankton, as also emphasized by Ptacnik et al. (2010).

The factors controlling seston composition are likely to vary both with time and between oceanic regions. Coastal river run-off is an important factor influencing seston composition in the two stations examined in this study, while others like nutrient limitation of phytoplankton, heterotrophic contribution and remineralization rates are likely to be important in the low-nutrient regime of the open oceans as well. The results in this study are based on observations from the coastal ocean, however they agree with the work by Marañon (2005) obtained in the oligotrophic ocean with a different approach (analysing phytoplankton growth rates). Namely that sestonic ratios close to the Redfield ratios do not necessarily imply a high contribution from phytoplankton under nutrient replete growth, and that seston elemental ratios is not a unambiguous indicator of phytoplankton physiological state.

The notions of fixed Redfield proportions in seston are convenient for calculating fluxes, mass-balance models and coupled biogeochemical models. Variable stoichiometry may be more realistic in many models (cf. Christian, 2005), yet it clearly also complicates model parameterization (e.g. Flynn, 2010). However, simulations with increased C:N (relative to the Redfield ratio) of sinking material has shown that negative feedbacks on atmospheric $\mathrm{CO}_{2}$ can be substantial, amounting to between 34 to $70 \mathrm{GtC}$ by the end of this century, depending on simulations (Schneider et al., 2004; Oschlies et al., 2008). These results show that variable stoichiometry in models has the potential to influence feedbacks in the ocean $\mathrm{C}$ cycle, and thereby climate, and is thus important to consider in future biogeochemical modelling efforts.

There is an expressed need to understand and quantify natural variability in seston elemental ratios (cf. Sterner and Elser, 2002), also in order to improve the empirical basis for parameterization of variable stoichiometry in models. In this respect it is important to recognize that the response of seston elemental ratios to parameters such as solar radiation, $\mathrm{CO}_{2}$ and nutrient concentrations will depend upon seston composition. Hence, to interpret the stoichiometric signal of seston to various ambient parameters, it is imperative to gain information on its composition and to realize that stable elemental ratios close to Redfield may not necessarily be indicative of "balanced growth" or a high contribution from phytoplankton.

Acknowledgements. This work was partially funded by the project Marine Ecosystem Response to a Changing Climate (MERCLIM No. 184860) financed by the program NORKLIMA through the Norwegian Research Council and by the European Union seventh framework program through the Marine Ecosystem Evolution in a Changing Environment (MEECE No. 212085) Collaborative Project and project EURO-BASIN (ENV.2010.2.2.1-1) under grant agreement number 264933. Gisle Nondal, Emil Jeansson, Truls Johannessen and Jan Magnusson are thanked for providing feedback on an earlier version of this manuscript. We are also grateful for the helpful comments by two reviewers. H. F. also wishes to thank E. K. S. for invaluable support. This is publication number A373 of the Bjerknes Centre for Climate Research.

Edited by: E. Marañón

\section{References}

Andersen, T. and Hessen, D. O.: Carbon, Nitrogen, and Phosphorus-Content of Fresh-Water Zooplankton, Limnol. Oceanogr., 36, 807-814, 1991.

Anderson, T. R. and Hessen, D. O.: Carbon or Nitrogen Limitation in Marine Copepods, J. Plankton Res., 17, 317-331, 1995.

Banse, K.: On the interpretation of data for the Carbon-to-Nitrogen ratio of phytoplankton, Limnol. Oceanogr., 19, 695-699, 1974.

Banse, K.: Determining the Carbon-to-Chlorophyll Ratio of Natural Phytoplankton, Mar. Biol., 41, 199-212, 1977.

Bates, N. R., Hansell, D. A., Bradley Moran, S., and Codispoti, L. A.: Seasonal and spatial distribution of particulate organic matter (POM) in the Chucki and Beaufort Seas, Deep-Sea Res., 52, 3324-3343, 2005.

Bellerby, R. G. J., Schulz, K. G., Riebesell, U., Neill, C., Nondal, G., Heegaard, E., Johannessen, T., and Brown, K. R.: Marine ecosystem community carbon and nutrient uptake stoichiometry under varying ocean acidification during the PeECE III experiment, Biogeosciences, 5, 1517-1527, doi:10.5194/bg-5-15172008, 2008.

Benschneider, K. and Robinson, R. J.: A new spectrophotometric method for the detection of nitrate in seawater, J. Mar. Res., 11, 87-96, 1952.

Cameron, A. C. and Windmeijer, A. G.: An R-squared measure of goodness of fit for some common nonlinear regression models, J. Econometrics, 77, 329-342, 1997.

Christian, J. R.: Biogeochemical cycling in the oligotrophic ocean: Redfield and non-Redfield models, Limnol. Oceanogr., 50, 646657, 2005. 
Copin-Montegut, C., and Copin-Montegut, G.: Stoichiometry of carbon, nitrogen and phosphorous in marine particulate matter, Deep-Sea Res., 30, 31-46, 1983.

Cotner, J. B., Hall, E. K., Scott, J. T., and Heldal, M.: Freshwater bacteria are stoichiometrically flexible with a nurient composition similar to seston, Front. Microbiol., 1, 132, doi:10.3389/fmicb.2010.00132, 2010.

DuRand, M. D., Olson, R. J., and Chisholm, S. W.: Phytoplankton population dynamics at the Bermuda Atlantic Time-series station in the Sargasson Sea, Deep-Sea Res., 48, 1983-2003, 2001.

Ehrhardt, M.: Determination of organic constituents, in: Methods of Seawater Analysis, edited by: Grasshoff, K., Ehrhardt, M., and Kremling, K., 2nd Edn., Verlag Chemie, Weinheimer, FRG, 1983.

Emerson, J. D. and Strenio, J.: Box plots and batch comparison, in: Understanding Robust and Explanatory Data Analysis, edited by: Hoaglin, D. C., Mosteller, F., and Tukey, J. W., J. Wiley \& Sons, 58-96, 2000.

Eppley, R. W., Chavez, F. P., and Barber, R. T.: Standing stocks of Particulate Carbon and Nitrogen in the Equatorial Pacific at 150²W, J. Geophys. Res., 97, 655-661, 1992.

Falck, E. and Anderson, L. G.: The dynamics of the carbon cycle in the surface water of the Norwegian Sea, Mar. Chem., 94, 43-53, 2005.

Flynn, K. J.: Ecological modelling in a sea of variable stoichiometry: Dysfunctionality and the legacy of Redfield and Monod, Prog. Oceanog., 84, 52-65, 2010.

Geider, R. J. and La Roche, J.: Redfield revisited: variability of $\mathrm{C}: \mathrm{N}: \mathrm{P}$ in marine microalgae and its biochemical basis, Eur. J. Phycol, 37, 1-17, doi:10.1017/S0967026201003456, 2002.

Goldman, J. C., Mccarthy, J. J., and Peavey, D. G.: Growth-Rate Influence on the Chemical Composition of Phytoplankton in Oceanic Waters, Nature, 279, 210-215, 1979.

Grasshoff, K.: On the automatic determination of silicate, phosphate and fluoride in seawater, ICES Hydrographic Commitee Report, 129, 1965.

Gundersen, K., Ocutt, K. M., Purdie, D. A., Michaels, A. F., and Knap, A. H.: Particulate organic carbon mass distribution at the Bermuda Atlantic Time-series Study (BATS) site, Deep-Sea Res., 48, 1697-1718, 2001.

Hansen, H. P. and Koroleff, F.: Determination of nutrients, in: Methods of Seawater Analysis, edited by: Grasshoff, K., Kremling, K. and Ehrhardt, M., 3rd Edn., Wiley - VCH Verlag, Weinheim, FRG, 1999.

Hessen, D. O., Andersen, T., Brettum, P., and Faafeng, B. A.: Phytoplankton contribution to sestonic mass and elemental ratios in lakes: Implications for zooplankton nutrition, Limnol. Oceanogr., 48, 1289-1296, 2003.

Hessen, D. O.: Efficiency, energy and stoichiometry in pelagic food webs; reciprocal roles of food quality and food quantity, Freshwater Rev., 1, 43-57, 2008.

Holm-Hansen, O., Lorenzen, C. J., Holmes, R. W., and Strickland, J. D. H.: Fluorementric Determination of Chlorophyll, ICES J. Mar. Sci., 30, 3-15, 1965.

Huisman, J., van Oostveen, P., and Weissing, F. J.: Species dynamics in phytoplankton blooms: Incomplete mixing and competition for light, Am. Nat., 154, 46-68, 1999.

Jeffrey, S. W. and Humphrey, G. F.: New spectrophotometric equations for detrmining chlorophylls a, b, c1 and c2 in higher plants, algae and natural phytoplankton, Biochem. Physiol. Pflanz, 167, 191-194, 1975.

Kiorboe, T.: Phytoplankton Growth-Rate and Nitrogen-Content Implications for Feeding and Fecundity in a Herbivorous Copepod, Mar. Ecol-Prog. Ser., 55, 229-234, 1989.

Klausmeier, C. A., Litchman, E., Daufresne, T., and Levin, S. A.: Optimal nitrogen-to-phosphorus stoichiometry of phytoplankton, Nature, 429, 171-174, 2004.

Klausmeier, C. A., Litchman, E., Daufresne, T., and Levin, S. A.: Phytoplankton stoichiometry, Ecol. Res., 23, 479-485, doi:10.1007/S11284-008-0470-8, 2008.

Koeve, W.: Spring bloom carbon to nitrogen ratio of net community production in the temperate N. Atlantic, Deep-Sea Res., 51, 1579-1600, doi:10.1016/J.Dsr.2004.07.002, 2004.

Koroleff, F.: Simultaneous oxidation of nitrogen and phosphorous compounds by persulfate, in: Methods of Seawater Analysis, edited by: Grasshoff, K., Ehrhardt, M., and Kremling, K., 2nd Edn., Verlag Chemie, Weinheimer, FRG, 1983.

Körtzinger, A., Koeve, W., Kahler, P., and Mintrop, L.: C:N ratio in the mixed layer during the productive season in the northeast Atlantic Ocean, Deep-Sea Res., 48, 661-688, 2001.

Lenton, T. M. and Watson, A. J.: Redfield revisited 1, Regulation of nitrate, phosphate, and oxygen in the ocean, Global Biogeochem. Cy., 14, 225-248, 2000.

Li, Y. H., Karl, D. M., Winn, C. D., Mackenzie, F. T., and Gans, K.: Remineralization ratios in the Subtropical North Pacific Gyre, Aqua. Geochem., 6, 65-86, 2000.

Marañón, E.: Phytoplankton growth rates in the Atlantic subtropical gyres, Limnol. Oceanogr., 50, 299-310, 2005.

Menden-Deuer, S. and Lessard, E. J.: Carbon to volume relationships for dinoflagellates, diatoms, and other protist plankton, Limnol. Oceanogr., 45, 569-579, 2000.

Menzel, D. W. and Ryther, J. H.: The composition of particulate organic matter in the western North Atlantic, Limnol. Oceanogr., 9, 179-186, 1964.

Michaels, A. F., Karl, D. M., and Capone, D. G.: Element stoichiometry, new production, and nitrogen fixation, Oceanography, 14, 68-77, 2001.

Norderhaug, K. M., Moy, F., Aure, J., Falkenhaug, T., Johnsen, T., Lømsland, E., Magnusson, J., Omli, L., Rygg, B., and Trannum, H. C.: Long-term monitoring of environmental quality in the coastal regions of Norway. Report for 2008, Norwegian Institute for Water Research (NIVA Report 5796), 2009 (In Norwegian).

Omta, A. W., Bruggeman, J., Kooijman, S. A. L. M., and Dijkstra, H. A.: Biological carbon pump revisited: Feedback mechanisms between climate and the Redfield ratio, Geophys. Res. Lett., 33, L14613, doi:10.1029/2006gl026213, 2006.

Oschlies, A., Schulz, K. G., Riebesell, U., and Schmittner, A.: Simulated 21st century's increase in oceanic suboxia by $\mathrm{CO} 2-$ enhanced biotic carbon export, Global Biogeochem. Cy., 22, GB4008, doi:10.1029/2007gb003147, 2008.

Osterroht, C. and Thomas, H.: New production enhanced by nutrient supply from non-Redfield remineralization of freshly produced organic material, J. Marine Syst., 25, 33-46, 2000.

Oubelkheir, K., Claustre, H., Sciandra, A., and Babin, M.: Bio-optical and biogeochemical properties of different trophic regimes in oceanic waters, Limnol. Oceanogr., 50, 1795-1809, 2005.

Pissierssens, P., Bergmans, M., and Polk, P.: On the need for inde- 
pendently estimating organic tripton carbon content, Mar. EcolProg. Ser., 25, 107-109, 1985.

Ptacnik, R., Andersen, T., and Tamminen, T.: Performance of the Redfield ratio and a family of derivatives as thresholds for phytoplankton N vs. P limitation, Ecosystems, 13, 1201-1214, 2010.

Quigg, A., Finkel, Z. V., Irwin, A. J., Rosenthal, Y., Ho, T. Y., Reinfelder, J. R., Schofield, O., Morel, F. M. M., and Falkowski, P. G.: The evolutionary inheritance of elemental stoichiometry in marine phytoplankton, Nature, 425, 291-294, doi:10.1038/Nature01953, 2003.

R Development Core Team, R: A language and environment for statistical computing, R Foundation for Statistical Computing, Vienna, Austria, ISBN 3-900051-07-0, available at: http://www. R-project.org/, 2011.

Redfield, A. C.: The biological control of chemical factors in the environment, American Scientist, 46, 205-221, 1958.

Riebesell, U., Schulz, K. G., Bellerby, R. G. J., Botros, M., Fritsche, P., Meyerhofer, M., Neill, C., Nondal, G., Oschlies, A., Wohlers, J., and Zollner, E.: Enhanced biological carbon consumption in a high $\mathrm{CO}_{2}$ ocean, Nature, 450, 545-549, doi:10.1038/Nature06267, 2007.

Schneider, B., Schlitzer, R., Fischer, G., and Nothig, E. M.: Depthdependent elemental composition of particulate organic matter (POM) in the ocean, Global Biogeochem. Сy., 17,1032, doi:10.1029/2002GB001871, 2003.

Schneider, B., Engel, A., and Schlitzer, R.: Effects of depthand $\mathrm{CO}_{2}$-dependent $\mathrm{C}: \mathrm{N}$ ratios of particulate organic matter (POM) on the marine carbon cycle, Global Biogeochem. Cy., 18, GB2015, doi:10.1029/2003gb002184, 2004.

Steele, J. H. and Baird, I. E.: Relations between Primary Production, Chlorophyll and Particulate Carbon, Limnol. Oceanogr., 6, 68-78, 1961.

Steele, J. H. and Baird, I. E.: The Chlorophyll a content of Particulate Organic Matter in the Norther North Sea, Limnol. Oceanogr., 10, 261-267, 1965.
Sterner, R. W., Andersen, T., Elser, J. J., Hessen, D. O., Hood, J. M., McCauley, E., and Urabe, J.: Scale-dependent carbon:nitrogen:phosphorous seston stochiometry in marine and fresh waters, Limnol. Oceanogr., 53, 1169-1180, 2008.

Sterner, W. R. and Elser, J. J.: Ecological Stoichiometry, the Biology of Elements from Molecules to the Biosphere, Princeton University Press, 2002.

Svansson, A.: Physical and chemical oceanography of the Skagerrak and the Kattegat, I. Open sea conditions, Report 1, Lysekil, 2-57, 1975.

Tett, P., Cottrell, J. C., Trew, D. O., and Wood, B. J. B.: Phosphorous quota and the chlorophyll: carbon ratio in marine phytoplankton, Limnol. Oceanogr., 20, 587-603, 1975.

Thomas, H.: Remineralization ratios of carbon, nutrients, and oxygen in the North Atlantic Ocean: a field databased assessment, Global Biogeochem. Cy., 16, 1051, doi:10.1029/2001GB001452, 2002.

Toggweiler, J. R.: Carbon Overconsumption, Nature, 363, 210-211, 1993.

Vadstein, O.: Heterotrophic, planktonic bacteria and cycling of phosphorus - Phosphorus requirements, competitive ability, and food web interactions, Adv. Microb. Ecol., 16, 115-167, 2000.

Valderrama, J. C.: The simultaneous Analysis of Total Nitrogen and Total Phosphorous in Natural waters, Mar. Chem., 10, 109-122, 1981.

Weber, T. S. and Deutsch, C.: Ocean nutrient ratios governed by plankton biogeography, Nature, 467, 550-554, doi:10.1038/Nature09403, 2010.

Wickham, H.: Ggplot2: elegant graphics for data analysis., Springer, New York, 978-0-387-98140-6, available at: http://had. co.nz/ggplot2/book, 2009.

Wienke, S. M. and Cloern, J. E.: The phytoplankton component of seston in San Francisco Bay, Neth. J. Sea Res., 21, 25-33, 1987. 